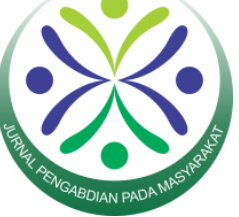

\title{
Pelatihan PMR Sadar Thalassemia Pada Kegiatan Jumbara XXV Kabupaten Banyumas
}

\author{
Lantip Rujito ${ }^{1}$, Diyah Woro Dwi Lestari ${ }^{2}$, Fitranto Arjadi ${ }^{3}$, Dinar Faiza ${ }^{4}$ \\ 1, 2,3 Universitas Jenderal Soedirman, ${ }^{4}$ Universitas Nahdlatul Ulama Purwokerto
}

\begin{tabular}{|c|c|}
\hline ARTICLE INFO & ABSTRACT \\
\hline Article History: & Thalassemia is a health condition that still needs treatment and serious \\
\hline Received 05.09.2018 & attention for the Indonesian government. As part of the thalassemia belt, \\
\hline Received in revised & Indonesia must act immediately to prevent the addition of thalassemia \\
\hline form 25.10.2018 & patients in the future. One of the mass educations that can be done is by self- \\
\hline Accepted 01.12.2018 & awareness movement among school students. Palang Merah Remaja (PMR) \\
\hline Available online & became a potential youth organization as the educator agent. Intense training \\
\hline 21.12.2018 & and debriefing on them can be a superior program for prevention among \\
\hline & $\begin{array}{l}\text { school students. Students, in this case, the Red Cross Youth who are at the } \\
\text { junior and senior high school level are potential cadres to spread the right }\end{array}$ \\
\hline
\end{tabular}

Keywords: PMR, Premarital Screening, Thalassemia Prevention.

This is an open access article distributed under the terms of the Creative Commons Attribution 4.0 International License, which permits unrestricted use distribution, and reproduction in any medium, provided the original work is properly cited. @ 2018 Lantip Rujito, Diyah Woro Dwi Lestari, Fitranto Arjadi, Dinar Faiza.

\section{PENDAHULUAN}

Banyumas dengan jumlah prevalensi pembawa sifat $8 \%$ menghadapi tantangan yang berat dalam penanganan paien thalassemia. Jumlah pasien saat ini mencapai kurang lebih 500 pasien, terdata pada pusat layanan thalassemia di RSU Banyumas. Jumlah ini meningkat tajam jika dibandingkan dengan sepuluh tahun yang lalu yang hanya sekitar 60 pasien (Rujito et al, 2015). Pencegahan menjadi satu-satunya jalan dalam penanganan penyaiti genetik ini. Kisah sukses pencegahan dan penanggulangan thalassemia sudah tercatat dalam histori penyakit ini. Negara mediteranian seperti Cyprus, Italia, mencanangkan program pencegahan sejak tahun 1980 an dan saat ini menuai hasil dengan tingkat insidensi thalassemia mayor $\sim 0 \%$. Hal yang dilakukan pertama kali oleh negara-negara tersebut adalah edukasi massal yang bersifat masif dan deteksi pembawa mutan thalassemia bagi setiap penduduk. Negara Asean lainnya mulai berbenah termasuk Thailand dan Malaysia sejak tahun 2010 (George, 2013). Negara tersebut sudah 
mencanangkan program pencegahan nasional dalam upaya penanggulangan penyakit thalassemia.

Indonesia dengan cakupan yang begitu luas, keanekaragaman budaya, dan penyebaran tenaga kesehatan masih belum memiliki program terpadu dalam pencegahan, namun masih bersifat pengobatan atau kuratif. Untuk mengisi kekurangan edukasi yang bersifat massal, Tim Thalassemia dari FK Unsoed bersama dengan pemerhati lainnya di wilayah Banyumas senantiasa berupaya aktif dalam penyebaran informasi dan pelatihan yang berkesinambungan. Pelajar dalam hal ini Palang Merah Remaja yang ada di tingkat SMP dan SMA merupakan kader yang potensial untuk menyebarkan informasi yang benar tentang thalassemia kepada teman sebayanya.

Salah satu upaya edukasi kepada remaja yang bersifat massal dilakukan dengan mengadakan pelatihan PMR Sadar Thalassemia pada Hajatan akbar Jumpa Bakti Gembira (Jumbara) PMR KE 25 yang digelar Palang Merah Indonesia (PMI) Kabupaten Banyumas pada tanggal 30 Agustus sampai dengan 3 September 2018 di Lapangan Desa Kemutugkidul Kecamatan Baturraden Kabupaten Banyumas. Jumbara sebagai ajang temu rutin tahunan para relawan kemanusiaan yang tergabung dalam PMR semua tingkatan, mulai dari tingkat SD (mula), SLTP (madya) dan SLTA (wira) (Octama, Hasyim, \& Adha, 2013: 3; Listiyanto, Purba, \& Pelana, 2017, p. 31). Kegiatan Jumbara di Kabupaten Banyumas diisi dengan berbagai kegiatan pelatihan dan aneka lomba dan diikuti sedikitnya 4000 PMR bersama pendamping.

\section{METODE PELAKSANAAN}

Pelatihan kader PMR mengedepankan aspek pengetahuan dan kemampuan mensosialisasikan ke teman sebaya. Metode edukasi ini yaitu dengan ceramah dan tanya jawab, pemaparan pengalaman dari pasien thalassemia, dan motivasi diri. Tim thalassemia FK Unsoed yang hadir adalah dosen genetik, dekan fk, orang tua serta pasien thalassemia. Peserta terdiri atas perwakilan PMR dari SMP dan SMA sebanyumas yang diwakili oleh 60 perwakilan. Dosen genetik memberikan pengetahuan dasar tentang klasifikasi thalassemia, aspek klinik, dampak sosial, dan upaya pencegahan. Perwakilan orang tua dan pasien memberikan testimoni tentang pengelolaan thalassemia. Pelatihan dibekali dengan leaflet dan juga brosur untuk memperjelas penyampaian materi.

\section{HASIL DAN PEMBAHASAN}

Palang Merah Remaja atau PMR adalah suatu organisasi binaan dari Palang Merah Indonesia yang berpusat di sekolah-sekolah ataupun kelompok-kelompok masyarakat (sanggar, kelompok belajar) yang bertujuan membangun dan mengembangkan karakter Kepalangmerahan agar siap menjadi Relawan PMI di masa depan (Prahesty \& Suwanda, 2016, p. 203). Kegiatan Ekstrakulikuler Palang Merah Remaja merupakan kegiatan di bidang kemanusiaan yang sangat erat kaitannya dengan orang lain (Rochmawati, 2013, p. 74). PMR dengan anggota lebih dari lima juta orang, anggota PMR merupakan salah satu kekuatan PMI dalam melaksanakan kegiatan-kegiatan kemanusiaan di bidang kesehatan dan siaga bencana, mempromosikan prinsip-prinsip dasar gerakan palang merah dan bulan sabit merah internasional, serta mengembangkan kapasitas organisasi PMI.

PMR Banyumas sudah ada sejak Palang Merah Indonesia beroperasi di wilayah Banyumas tahun 1950 (Irsyad, 2017). PMR Banyumas terdiri atas PMR Mula pada tingkat Sekolah Dasar, PMR Madya pada tingkat Sekolah Menengah Pertama, dan PMR Wira 
pada tingkatan Sekolah Menengah Atas. Anggota PMR pada kegiatan kali ini adalah anggota Madya dan Wira, terdiri atas 30 siswa SMP dan 30 Siswa SMA. Usia mereka antara 11 tahun sampai 16 tahun, terdiri atas 45 perempuan dan 15 laki-laki. Tersebar merata atas semua wilayah Banyumas, mulai dari wilayah timur Kecamatan Tambah, sampai ke arah barat sampai Kecamatan Lumbir.

Materi pelatihan kepada PMR menitikberatkan kepada kesadaran bahwa Thalassemia adalah penyakit genetik yang mudah dicegah. Pencegahan melibatkan kesadaran diri dari para anggota PMR untuk ikut terlibat dalam sosialisasi thalassemia di sekolahnya sekaligus mampu secara sadar untuk memeriksakan status pembawa mutan pada dirinya.

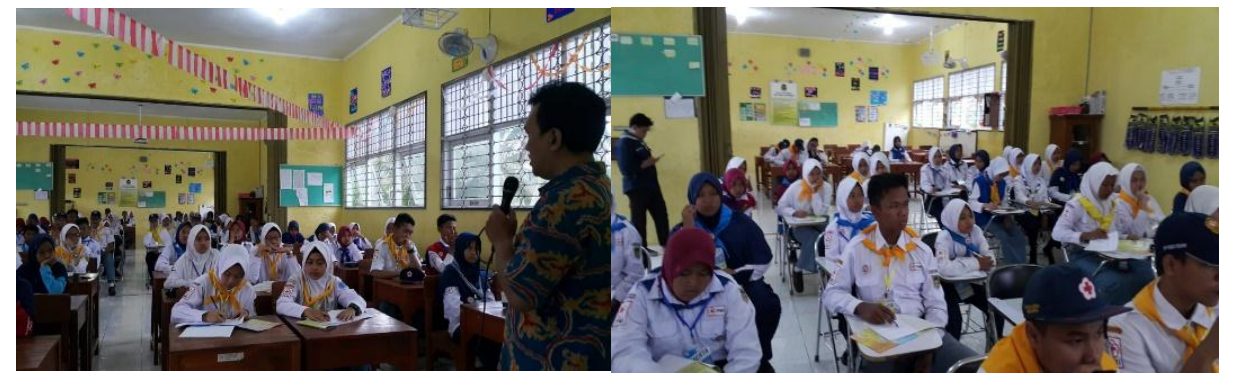

Gambar 1. Dokumentasi Pelaksanaan Kegiatan

Pelajar mendapatkan materi bahwa klasifikasi thalassemia dibagi atas beberapa golongan. Yang paling utama adalah klasifikasi klinis dimana thalassemia terbagai atas 3 golongan utama yaitu thalassemia mayor, thalassemia, intermedia, dan thalassemia minor. Thalassemia mayor merupakan penderita yang sebenarnya, sedangkan intermedia merupakan kondisi pasien thalassemia yang tidak rutin dalam penanganan kondisi klinisnya. Dua kondisi ini memerlukan tindakan suportif transfusi dan meminum obat kelasi besi. Kondisi klinis akan muncul pada anak usia 1 tahunan berupa pucat dan semua gejala klinis anemia (Thein, 2018). Kondisi ini bukan ranah PMR untuk terlibat dalam penanganan thalassemia.

Thalassemia minor atau pembawa sifat atau pembawa mutan adalah titik berat penjelasan tim kepada para anggota PMR. Sifat thalassemia minor yang tidak menunjukkan gejala menjadi penting untuk diketahui dan menjadi perhatian para anggota PMR. Thalassemia minor adalah kondisi dimana individu memiliki salah satu alel gen thalassemia yang eror atau mengalami mutasi, sedangkan alel yang lainnya normal. Individu menampakan kondisi yang sehat, sama dengan manusia normal lainnya. Kondisi minor umumnya diketahui ketika tanpa sengaja melakukan pemeriksaan hematologi darah karena suatu hal. Umumnya Hb akan normal atau sedikit lebih rendah dengan MCV kurang dari $80 \mathrm{fl}$ dan $\mathrm{MCH}$ kurang dari $27 \mathrm{pg}$. Pada gambaran apusan darah tepi, sel akan terlihat sedikit lebih pucat dan terlihat ukuran sel yang lebih kecil atau disebut mikrositik hipokromik.

Kelainan minor inilah yang menjadi fokus pencegahan dimasa generasi mendatang. Seseorang yang sehat seyogyanya melakukan cek status mutan pada dirinya. Apakah dia seorang karier atau pembawa mutan atau tidak. Hal ini penting untuk menghindari bertemunya dua gen mutan pada anak akibat perkawinan dua pembawa sifat thalassemia. Peran PMR adalah mengkampanyekan pemeriksaan status karier ini kepada teman sebaya di sekolahnya dan menjadi tempat konsultasi thalassemia bagi para warga sekolah. Skrining thalassemia sebelum 'pacaran' atau menikah menjadi cara efektif untuk mencegah thalassemia pada anak keturunan dii masa mendatang. Anak-anak PMR 
dibekali pengetahuan yang cukup untuk ikut serta mendorong pelaksanaan skrining secara mandiri oleh teman-teman sebayanya di sekolah.

Pada akhir sesi pemarapan, diselenggarakan dialog dan tanya jawab untuk memperjelas materi yang belum bisa dicerna dengan baik. Tanya jawab dikemas dengan menarik karena disediakan doorprice dan terlibatnya para pasien thalassemia secara langsung untuk memberikan edukasi kepada para anggota PMR.

PMR juga dibekali dengan perangkat leaflet dan brosur untuk mempermudah penjelasan kepada teman sebayanya. Mereka mendapatkan brosur dan leaflet secara gratis dan diberi bekal kontak person yang dapat dihubungi untuk pertanyaanpertanyaan yang tidak bisa diselesaikan. Pembekalan PMR ini semoga dapat ditindaklanjuti oleh pemerintah pusat atau daerah untuk menggalakan sebuah sistem pencegahan thalassemia berbasis komunitas atau masyarakat. Harapannya, pemerinta menanggapi dengan serangkaian program pencegahan yang bersifat permanen dan menyentuh seluruh lapisan masyarakat.

\section{SIMPULAN}

Pembekalan keterampilan penyuluhan pada anggota Palang Merah Remaja (PMR) merupakan salah satu cara edukasi masyarakat sekolah untuk ikut berperan serta dalam upaya pencegahan thalassemia di kalangan pelajar. Kegiatan pelatihan ini seyogyakanya ditindaklanjuti dengan program skrining pembawa atau karier thalassemia di kalangan pelajar sekolah.

\section{REFERENSI}

George, E. (2013). HbE $\beta$-Thalassaemia in Malaysia: Revisited. Journal of Hematology $\mathcal{E}$ Thromboembolic Diseases, 1, 101.

Irsyad. (Ed.) (2017). Sejarah PMI. Retrieved November 2, 2018 from https://pmibanyumas.or.id/index.php/tentang-kami/sejarah-pmi.

Listiyanto, D., Purba, R. H., \& Pelana, R. (2017). Pengetahuan anggota korps sukarela palang merah indonesia (KSR PMI) Unit universitas negeri jakarta mengenai penanganan cedera olahraga. SEGAR, 5(1), 29-40.

Octama, R., Hasyim, A., \& Adha, M. M. (2013). Pengaruh ekstrakurikuler palang merah remaja (PMR) terhadap sikap sosial siswa SMA. Jurnal Kultur Demokrasi, 1(6), 1-14.

Prahesty, R. E., \& Suwanda, I. M. (2016). Peran ekstrakurikuler palang merah remaja dalam membentuk sikap tolong menolong siswa di SMPN 5 Sidoarjo. Kajian Moral dan Kewarganegaraan, 1(4), 201-215.

Rochmawati, E. (2013). Palang merah remaja sebagai wadah pengembangan perilaku menolong di kalangan siswa SMA Negeri 9 Semarang. Solidarity: Journal of Education, Society and Culture, 2(2), 72-79.

Rujito, L., Basalamah, M., Mulatsih, S., \& Sofro, A. S. M. (2015). Molecular scanning of $\beta$ thalassemia in the Southern Region of Central Java, Indonesia; a step towards a local prevention program. Hemoglobin, 39(5), 330-333.

Thein, S. L. (2018). Molecular basis of $\beta$ thalassemia and potential therapeutic targets. Blood Cells, Molecules, and Diseases, 70, 54-65. 